\title{
Ekstraksi Fitur Warna, Tekstur dan Bentuk untuk Clustered-Based Retrieval of Images (CLUE)
}

\author{
I Gusti Rai Agung Sugiartha ${ }^{1}$, Made Sudarma ${ }^{2}$, I Made Oka Widyantara ${ }^{3}$
}

\begin{abstract}
Picture (image) is a media that used for storing visual data, for example, two-dimensional images are often used to store an incident. Images on the internet media growth very rapidly. There are a lot of image, video, text or other content on the Internet. Image Index and image retrieval again become a topic of research in the last decade in which concentrated on how to get the meaning of an information contained in an image. Three methods outlined in the search for an image, the textbased image retrieval, content-based image retrieval and indexing images in the order of language. This study focuses on the preparation of the features of an image based on color and texture. Features colors using the average value of Hue image, texture features using Gray Level occurance Matrix (GLCM). Color, texture, and shape extraction technique resulted in eighteen (18) feature that can be used as features in the process of Clustering. Measurement of the image retrieval have highest recall value at 1 and precisions value of 0.44
\end{abstract}

Intisari- Gambar(citra) merupakan media yang digunakan untuk menyimpan data visual, sebagai contoh gambar dua dimensi yang sering dipergunakan untuk menyimpan suatu kejadian. Tidak bisa dipungkiri kebiasaan untuk menyimpan gambar pada media internet sangat pesat. Terdapat banyak konten gambar, video, teks atau konten yang lainnya di jaringan Internet. Image Index dan images retrieval merupakan teknik untuk bagaimana cara mendapatkan makna dari sebuah informasi yang terkandung dalam sebuah gambar. Tiga metode secara garis besar dalam image retrieval, yaitu image retrieval berbasis teks, berbasis konten, dan image retrieval dengan tatanan bahasa. Penelitian ini berfokus pada penyiapan fitur dari sebuah gambar berdasarkan warna, tekstur, dan bentuk. Fitur warna menggunakan metode Color Histogram, fitur tekstur menggunakan Gray Level Occurance Matrix (GLCM), dan bentuk menggunakan Edge Direction metode Canny Edge Detection. Teknik ektraksi warna, tekstur, dan bentuk menghasilkan 18 (delapan belas) buah fitur yang mampu digunakan sebagai fitur di proses Clustering gambar.Pengukuran pencarian gambar menunjukkan penggunaan fitur bentuk memiliki nilai pengukuran tertinggi yaitu recall sebesar 1 dan precision sebesar 0,44 .

Kata Kunci- Ektraksi Fitur Warna, Ektraksi Fitur Tekstur Ektraksi Fitur Bentuk, Gray Level Occurance Matrix, ClusteredBased Retrieval of Images.

\section{PENDAHULUAN}

Gambar(citra) merupakan media yang digunakan untuk menyimpan data visual, sebagai contoh gambar dua dimensi yang sering dipergunakan untuk menyimpan suatu kejadian.

\footnotetext{
${ }^{I}$ MahasiswaMagisterTeknik Elektro dan Komputer, Universitas Udayana, Kampus Sudirman, Denpasar-Bali (telp:0361239599, email: rai_sugiartha@gmail.com)

${ }^{2,3}$ Dosen MagisterTeknik Elektro dan Komputer, Universitas Udayana, Kampus Sudirman, Denpasar-Bali (telp:0361239599, email:msudarma@unud.ac.id,) oka.widiantara @unud.ac.id)
}

I Gusti Rai Agung Sugiartha:Ekstraksi Fitur Warna, Tekstur....
Gambar akan menyimpan data dan bisa dijadikan sebuahinformasi. Gambar akan dikumpulkan pada sebuah tempat yang kemudian hari bisa diambil dan dipergunakan. Tidak bisa dipungkiri kebiasaan untuk menyimpan gambar pada media internet sangat pesat. Terdapat banyak konten gambar, video, teks atau konten yang lainnya di jaringan Internet. Ini memberikan manfaat apabila ada pengguna yang berkeinginan menggunakan sebuah gambar dengan tema tertentu. Proses pencarian dan penjelajahan sebuah gambar pada sekumpulan gambar yang banyak tentu akan membutuhkan waktu yang sangat lama.

Chen Yixin (2004) mengungkapkan image retrieval dengan teknik indeks makna gambar secara otomatis merupakan hal yang sangat penting keberadaanya, pengenalan objek dan memahami gambar. Ini merupakan teknik diantara teknik temu dengan teks dan konten. Diperkenalkan juga skema CLUE (Clustered-based rEtrieval of images) dengan menggunakan pembelajaran mesin tanpa pengawasan (machine unsupervised learning) dengan menggunakan metode clustering yang berbasiskan dari kemiripan konten yang dijadikan acuan pencarian oleh pengguna [1].

Feature Extraction atau ekstraksi ciri merupakan proses pengindeksan suatu database citra dengan isinya. Secara matematik, setiap ekstraksi ciri merupakan encode dari vector $\mathrm{n}$ dimensi yang disebut dengan vector ciri. Komponen vector ciri dihitung dengan pemrosesan citra dan teknik analisis serta digunakan untuk membandingkan citra yang satu dengan citra yang lain. Ekstraksi ciri diklasifikasikan ke dalam 3 jenis yaitu low-level, middle-level, dan high-level. Low-level merupakan ekstraksi ciri berdasarkan isi visual seperti warna dan tekstur, middle-level merupakan ekstraksi berdasarkan wilayah citra yang ditentukan dengan segmentasi, sedangkan high-level merupakan ekstraksi ciri berdasarkan informasi semantic yang terkandung dalam citra [2].

Penelitian ini menerapkan fitur ekstraksi warna dengan color histogram, fitur ektraksi tekstur dengan Gray Level oCcurance Matrix(GLCM) dan fitur ekstraksi bentuk dengan Edge Direction Histogram metode Canny Edge Detection. Citra yang digunakan untuk uji coba model yang dikembangkan ini adalah beberapa citra uji dari Corel Database Dataset. Untuk mengetahui unjuk kerja dari fitur ekstraksi mempergunakan metode pengujian recall dan precision [3].

\section{METODE PENELITIAN}

\section{A. Gambaran Umum Sistem}

Gambar 1 menunjukan gambaran umum sistem dari penelitian yang diusulkan. Citra sampel yang digunakan dalam penelitian ini diperoleh dari Corel Database Dataset.

p-ISSN:1693 - 2951; e-ISSN: 2503-2372 
Pengujian menggunakan 1.435 gambar latih yang dibedakan menjadi 13 kelompok gambar, yaitu kategori gambar: Anjing, Beruang, Bus, Dinosaurus, Gajah, Hutan, Ikan, Kucing, Kuda, Kupu-kupu, Mawar, Pantai, dan Pemandangan. Hasil uji coba sistem ini dievaluasi menggunakan dua pendekatan yaitu metode recall dan precision dengan mengukur nilai kesesuaian gambar uji dengan gambar latih.

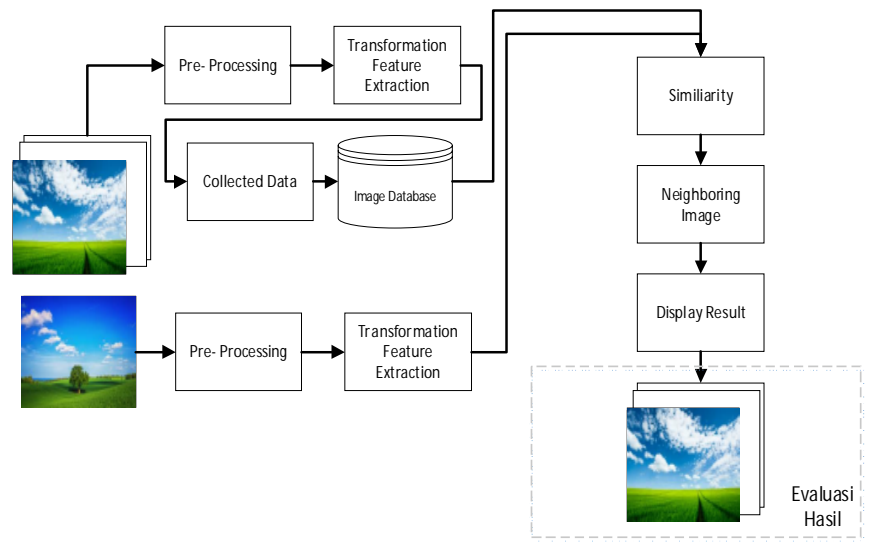

Gambar 1: Gambaran Umum Sistem

\section{B. Data Uji}

Citra latih dan citra uji yang digunakan pada penelitian ini adalah Corel Database Dataset yang diperoleh dari Corel Photo Gallery [4]. Berbagai macam citra uji dengan beragam variasi dan karakteristik tersebut dibungkus kedalam sebuah dataset yang dapat diunduh secara gratis. Dari sekian banyak citra uji yang tersedia, pada penelitian ini hanya digunakan 1.435 buah citra latih yang sudah dipilih berdasarkan karakteristik warna yang bervariasi, dapat dilihat pada gambar 2 .
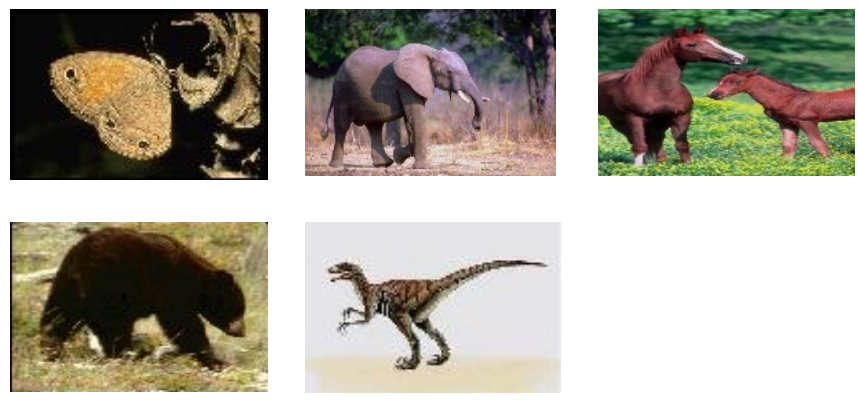

Gambar 2: Kategori citra latih: (a) kupu-kupu, (b) gajah,(c) kuda, (d) beruang, (e) dinosaurus

\section{Preprocessing}

Pre-processing gambar latih merupakan langkah untuk meningkatkan kualitas gambar. Gambar mengalami transformasi untuk menghasilkan fitur penting dari sebuah gambar. Pada aplikasi penelitian ini menggunakan teknik perubahan aras warna gambar, yaitu dari gambar berwarna menjadi gambar abu-abu(grayscale). Pengubahan aras warna menjadi gambar abu-abu juga akan menurunkan tingkat komputasi pada tahap pengambilan fitur.

\section{Ekstraksi Fitur Warna}

Gambar tersusun dari piksel-piksel yang memiliki ukuran intensitas warna masing-masing. Sebaran warna di tiap-tiap piksel ditunjukkan oleh histogram. Histogram menunjukkan distribusi piksel berdasarkan intensitas graylevel (derajat keabuan) yang dimiliki tiap-tiap piksel. Penggunaan histogram sebagai metode ekstraksi ciri didasarkan pada perbedaan sebaran atau distribusi piksel di masing-masing gambar. Pada proses ektraksi ciri warna diawali dengan merubah aras warna RGB menjadi aras keabuan (grayscale). Nilai warna keabuan dari masing-masing piksel yang menyusun gambar di kelompokkan menjadi 8 kelompok rentang nilai piksel warna (bin). Tiap kelompok jumlah anggota kemudian dinormalisasi dengan cara di bagi dengan hasil perkalian panjang dan lebar gambar (banyak piksel warna penyusun gambar).

\section{E. Ekstraksi Fitur Tekstur}

Ciri tekstur merupakan ciri penting dalam sebuah gambar yang merupakan informasi berupa susunan struktur permukaan suatu gambar. Dalam penelitian ini menggunakan Gray Level oCcurance Matrix (GLCM) sebagai matrik pengambilan nilai keabuan dari sebuah gambar. Berikut merupakan tahapan yang digunakan dalam pengambilan ciri tekstur dari sebuah gambar.

1) Citra warna dirubah menjadi citra grayscale

2) Masing-masing nilai dari RGB citra dirubah menjadi abuabu dengan menggunakan rumus sebagai berikut: keabuan $=0.2989 * \mathrm{R}+0.5870 * \mathrm{G}+0.1140 * \mathrm{~B}$

3) Piksel baru $=\operatorname{setPixel}(255$, nilai keabuan, nilai keabuan, nilai keabuan)

4) Segmentasi nilai warna ke dalam 16 bin

5) Hitung nilai-nilai co-occurance matrix dalam empat arah masing-masing $0^{0}, 45^{\circ}, 90^{\circ}$, dan $135^{\circ}$

6) Hitung informasi ciri tekstur yaitu yaitu contrast, correlation, energy, homogeneity, dan entropy

Contrast dihitung dengan persamaan berikut:

$$
\sum_{k} k^{2}\left[\sum_{i} \sum_{j} p(i, j)\right]
$$

Correlation dihitung dengan persamaan berikut:

$$
\sum_{i, j} \frac{\left(i-\mu_{i}\right)\left(j-\mu_{j}\right) P(i, j)}{\sigma_{i} \sigma_{j}}
$$

Energy dihitung dengan persamaan berikut:

$$
\sum_{i, j} P(i, j)^{2}
$$

Homogeneity dihitung dengan persamaan berikut:

$$
\sum_{i, j} \frac{P(i, j)}{1+|i-j|}
$$

Entropy dihitung dengan persamaan berikut:

$$
\text { - } \sum_{i, j} P(i, j) \log P(i, j)
$$

\section{F. Ekstraksi Fitur Bentuk}

Ciri bentuk merupakan karakter dari suatu objek yang merupakan konfigurasi oleh garis dan kontur. Fitur bentuk dikategorikan bergantung pada teknik yang digunakan. Kategori tersebut adalah berdasarkan batas (boundary-based) 
dan berdasarkan daerah (region-based). Teknik berdasarkan batas (boundary-based) menggambarkan bentuk daerah dengan menggunakan karakteristik ekstrenal, contohnya adalah piksel sepanjang batas objek. Dalam penelitian ini menggunakan metode Canny Edge Detection yang dipergunakan untuk menemukan bagian-bagian tepi dari sebuah objek. Edge detection adalah menemukan bagian pada citra yang mengalami perubahan intensitas warna secara drastis. Algoritma Canny Edge Detection secara umum beroperasi sebagai berikut:

1) Penghalusan untuk mengurangi dampak noise terhadap pendeteksian tepi

2) Menghitung potensi gradient citra

3) Non-maximal suppression dari gradient citra untuk melokalisasi edge secara presisi

4) Hysteresis thresholding untuk melakukan klasifikasi akhir

\section{G. Perbandingan Kemiripan}

Proses perbandingan kemiripan dari hasil klaster citra merupakan hasil dari ekstraksi ciri warna, ekstraksi ciri bentuk dan ekstraksi ciri tekstur. Keanggotaan suatu citra dalam klastering yang terbentuk akan menjadi pembanding untuk gambar uji yang dimasukkan. Metode yang dipakai untuk mengukur jarak antar dua centroid adalah menggunakan Manhattan Distance dirumuskan sebagai berikut [6]

$$
\operatorname{Total}[\mathrm{Abs}[\mathrm{u}-\mathrm{v}]]
$$

dengan $u$ dan $v$ merupakan vector. Dalam penelitian ini $u$ merupakan atribut fitur citra uji dan $v$ merupakan atribut fitur citra latih dan citra uji. Setelah centroid yang memiliki jarak paling dekat tadi ditemukan.

\section{H. Pengujian dan Evaluasi Hasil}

Pengujian dilakukan dengan memproses fitur ekstraksi gambar latih, kemudian dihitung perbandingan kemiripan dengan fitur ekstraksi gambar uji. Pengujian menggunakan 13 kelompok gambar latih dan 2 gambar uji. Evaluasi hasil menggunakan dua pendekatan sebagai berikut.

Pengukuran unjuk kerja sistem yang dikembangkan ini dilakukan dengan mengukur kualitas hasil pencarian gambar yang melibatkan gambar latih dengan gambar uji. Pengukuran menggunakan metode Recall dan Precisión[3].

Recall $=\frac{\mid\{\text { relevant document }\} \cap\{\text { retrieved document }\} \mid}{\mid\{\text { relevant document database }\} \mid}$

denganrelevant document : banyak gambar yang sesuai dengan gambar uji dari gambar yang ditampilkan sistem.

retrieved document : banyak gambar yang ditampilkan oleh sistem sesuai dengan gambar uji.

relevant document database: banyak gambar yang sesuai dengan gambar uji yang disimpan dalam basis data.

Precision $=\frac{\mid\{\text { relevant document }\} \cap\{\text { retrieved document }\} \mid}{\mid\{\text { retrieved } \text { document }\} \mid}$

denganrelevant document : banyak gambar yang sesuai dengan gambar uji dari gambar yang ditampilkan sistem.

retrieved document : banyak gambar yang ditampilkan oleh sistem sesuai dengan gambar uji.

I Gusti Rai Agung Sugiartha:Ekstraksi Fitur Warna, Tekstur....

\section{HASIL DAN PEMBAHASAN}

Sistem image retrieval yang dikembangkan menggunakan bahasa pemrograman C\# dan mesin basis data SQL Server 2008.Pengujian sistem ini dilakukan dengan mempersiapkan gambar latih terlebih dahulu dengan proses praprocessing terlebih dahulu seperti terlihat di gambar 3 .

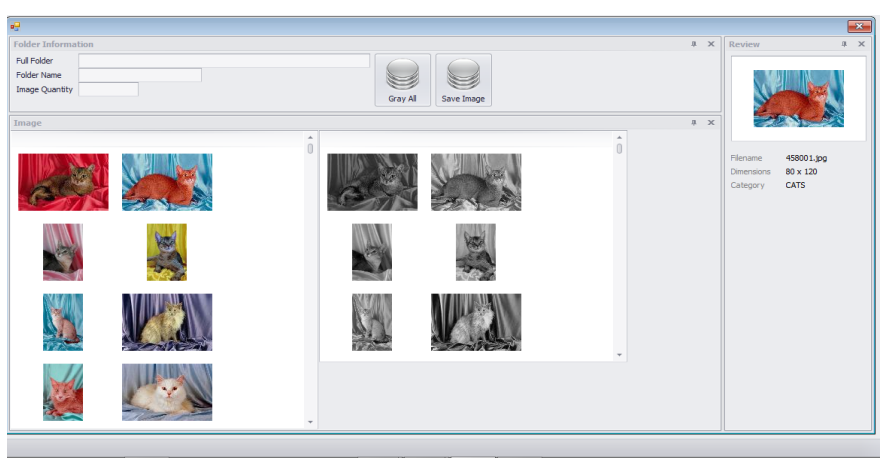

Gambar3: Halaman Pre-processing grayscale gambar latih

Proses selanjutnya adalah pengambilan ekstraksi fitur warna, fitur tekstur, dan fitur bentuk dari masing-masing gambar latih. Pengambilan fitur warna terlihat pada gambar 4, pengambilan fitur tekstur terlihat pada gambar 5, dan pengambilan fitur bentuk terlihat pada gambar 6 .

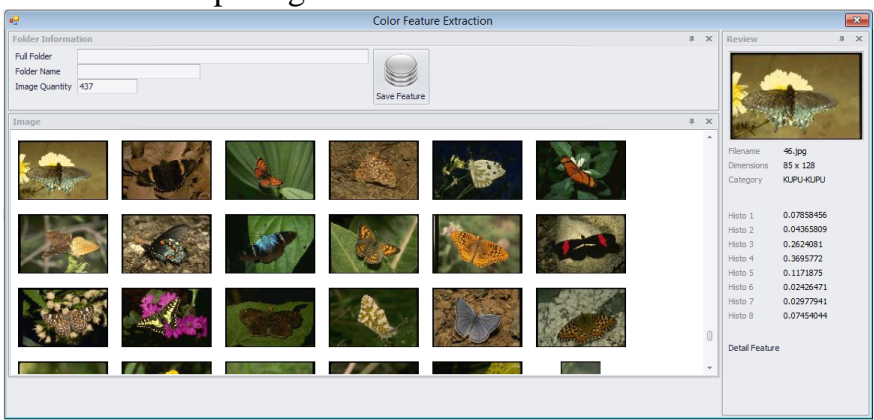

Gambar4: Halaman Pengambilan Fitur Warna Gambar Latih

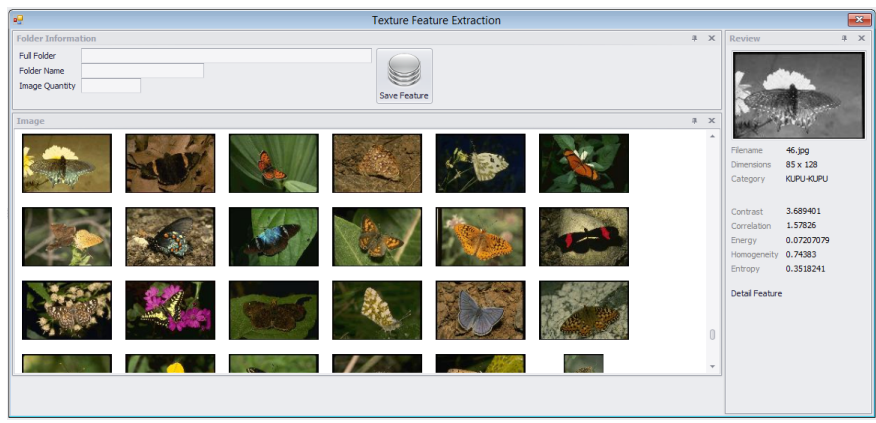

Gambar5: Halaman Pengambilan Fitur Tekstur Gambar Latih

p-ISSN:1693 - 2951; e-ISSN: 2503-2372 


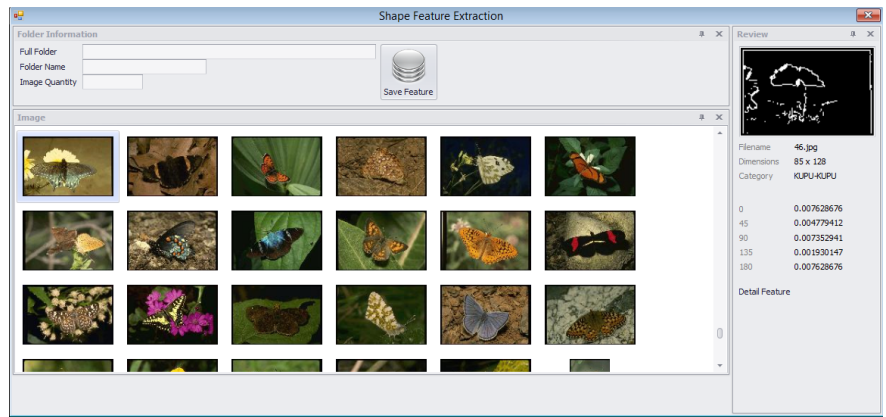

Gambar6: Halaman Pengambilan Fitur Bentuk Gambar Latih

Pengujian unjuk kerja sistem yang dikembangkan dengan menguji image retrieval dengan gambar uji. Gambar uji yang dipergunakan adalah gambar dari kategori gajah dan gambar kategori bus.

Seperti langkah persiapan gambar latih, gambar uji yang dipergunakan juga melalui proses para-processing dan pengambilan fitur warna, tekstur, dan bentuk. Hasil perhitungan jarak antar fitur-fitur gambar latih dengan gambar uji terlihat seperti pada gambar 7 .

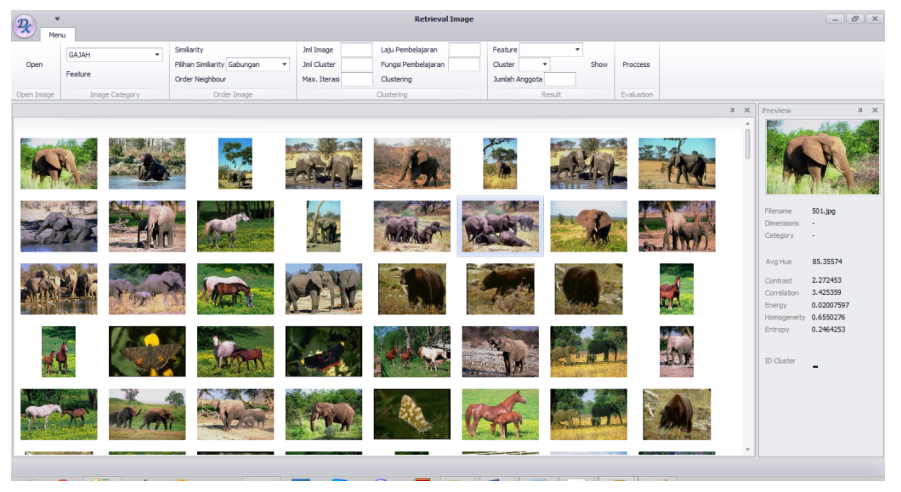

Gambar7: Halaman Similiarity Fitur Gambar Latih dengan Gambar Uji

Hasil pengukuran pencarian gambar kategori gajah terlihat pada tabel 1. Pencarian gambar dengan kategori Gajah terlihat lebih bagus mempergunakan gabungan fitur warna, tekstur dan bentuk. Nilai precision dari penggunaan fitur gabungan menunjukkan nilai 0,33 ketika menggunakan gambar latih sebanyak 100 gambar. Nilai precision yang terbaik adalah nilai yang mendekati nilai 1 .

TABEL 1 Hasil PENGUKuRAn PENCARIAn Gambar Kategori Gajah

\begin{tabular}{|c|c|c|c|c|}
\hline \multirow[t]{2}{*}{ Gambar Uji } & \multirow[t]{2}{*}{ Fitur } & \multirow{2}{*}{$\begin{array}{c}\text { Jml } \\
\text { Gambar }\end{array}$} & \multicolumn{2}{|c|}{ Retrieval } \\
\hline & & & Recall & Precision \\
\hline & Warna & 100 & 1 & 0.32 \\
\hline & Tekstur & 100 & 1 & 0.22 \\
\hline & Bentuk & 100 & 1 & 0.26 \\
\hline & Gabungan & 100 & 1 & 0.33 \\
\hline & Warna & 200 & 1 & 0.23 \\
\hline & Tekstur & 200 & 0.53 & 0.22 \\
\hline & Bentuk & 200 & 1 & 0.15 \\
\hline & Gabungan & 200 & 0.45 & 0.25 \\
\hline
\end{tabular}

\begin{tabular}{|c|c|c|c|c|}
\hline Gambar Uji & Fitur & Jml & \multicolumn{2}{|c|}{ Retrieval } \\
\cline { 4 - 5 } & & Gambar & Recall & Precision \\
\cline { 2 - 5 } & Warna & 300 & 1 & 0.26 \\
\cline { 2 - 5 } & Tekstur & 300 & 0.6 & 0.27 \\
\cline { 2 - 5 } & Bentuk & 300 & 1 & 0.18 \\
\cline { 2 - 5 } & Gabungan & 300 & 0.51 & 0.28 \\
\hline
\end{tabular}

Pengukuran kualitas masing-masing hasil ektraksi fitur menggunakan beberapa gambar latih, dimana gambar latih yang dipergunakan adalah gambar latih yang memiliki nilai kedekatan paling kecil dengan gambar uji. Gambar latih yang dipergunakan terlihat di gambar 8 .

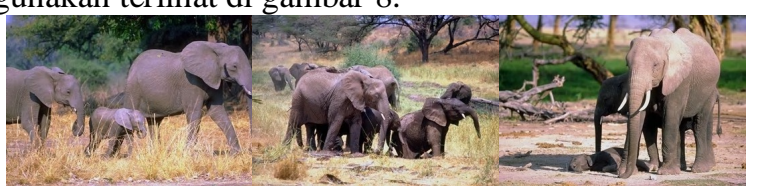

(a)

(b)

(c)

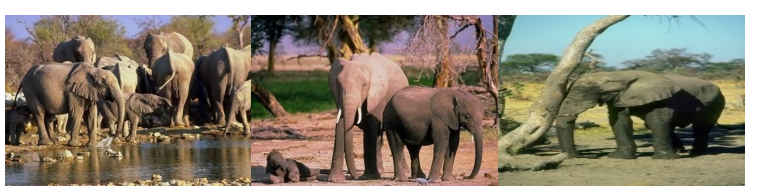

(d)

(e)

(f)

Gambar8: Gambar latih jarak kedekatan terkecil dengan gambar uji kategori gajah

Perhitungan jarak nilai fitur gambar uji dengan fitur gambar latih diperlihatkan pada tabel 2 untuk fitur warna, tabel 3 untuk fitur tekstur, dan tabel 3 untuk fitur bentuk.

TABEL 2 HASIL PENGUKURAN JARAK FITUR WARNA KATEGORI GAJAH

\begin{tabular}{|c|c|c|c|c|c|c|c|c|c|}
\hline \multirow{2}{*}{ Gambar } & \multicolumn{7}{|c|}{ Fitur Warna } & $\begin{array}{c}\text { Jarak } \\
\text { (Manhattan } \\
\text { Distance })\end{array}$ \\
\cline { 2 - 9 } & 1 & 2 & 3 & 4 & 5 & 6 & 7 & 8 & 0.2808 \\
\hline $\mathrm{a}$ & 0.1001 & 0.0675 & 0.106 & 0.1262 & 0.2387 & 0.1843 & 0.1761 & 0.001 & 0.1089 \\
\hline $\mathrm{b}$ & 0.0711 & 0.0893 & 0.1335 & 0.1868 & 0.187 & 0.2071 & 0.1176 & 0.0076 & 0.32 \\
\hline $\mathrm{c}$ & 0.1006 & 0.1434 & 0.1591 & 0.2584 & 0.1739 & 0.1087 & 0.0502 & 0.0056 & 0.1525 \\
\hline $\mathrm{d}$ & 0.1066 & 0.0827 & 0.1286 & 0.2407 & 0.1898 & 0.1648 & 0.0836 & 0.0032 & \\
\hline $\mathrm{e}$ & 0.0782 & 0.1034 & 0.1416 & 0.1749 & 0.1767 & 0.1922 & 0.1245 & 0.0085 & 0.1449 \\
\hline $\mathrm{f}$ & 0.1153 & 0.1601 & 0.1624 & 0.1884 & 0.1932 & 0.1502 & 0.0295 & 0.0009 & 0.3357 \\
\hline uji & 0.0973 & 0.0588 & 0.1341 & 0.2145 & 0.173 & 0.206 & 0.113 & 0.0034 & \\
\hline & & & & & & & & & \\
\hline
\end{tabular}

TABEL 3 Hasil Pengukuran jarak fitur Tekstur kategori Gajah

\begin{tabular}{|c|c|c|c|c|c|c|}
\hline \multirow{2}{*}{ Gambar } & \multicolumn{5}{|c|}{ Fitur Tekstur } & $\begin{array}{c}\text { Jarak } \\
\text { (Manhattan Distance) }\end{array}$ \\
\cline { 2 - 6 } & Contrast & Correlation & Energy & Homogenity & Entropy & \\
\hline a & 1.3897 & 0.0475 & 0.7662 & 3.5205 & 0.3072 & 0.5783 \\
\hline b & 1.67 & 0.0229 & 0.691 & 2.9464 & 0.2554 & 0.4343 \\
\hline c & 1.7863 & 0.0276 & 0.7201 & 2.9725 & 0.2661 & 0.48 \\
\hline d & 1.3421 & 0.0296 & 0.7275 & 3.1842 & 0.2715 & 0.2887 \\
\hline e & 1.4758 & 0.0266 & 0.7437 & 3.524 & 0.2656 & 0.6663 \\
\hline f & 1.4411 & 0.0279 & 0.7378 & 3.3489 & 0.2697 & 0.457 \\
\hline uji & 1.3864 & 0.034 & 0.7619 & 2.9888 & 0.2817 & \\
\hline & & & & & & \\
\hline
\end{tabular}

ISSN 1693-2951 I Gusti Rai Agung Sugiartha: Ekstraksi Fitur Warna, Tekstur.... 
Teknologi Elektro, Vol. 16, No1, Januari-April 2017

TABEL 4 Hasil Pengukuran jarak fitur Bentuk kategori Gajah

\begin{tabular}{|c|c|c|c|c|c|c|}
\hline \multirow{2}{*}{ Gambar } & \multicolumn{5}{|c|}{ Fitur Bentuk } & $\begin{array}{c}\text { Jarak } \\
\text { (Manhattan Distance })\end{array}$ \\
\cline { 2 - 6 } & $0^{0}$ & $45^{0}$ & $90^{0}$ & $135^{0}$ & $180^{0}$ & \\
\hline $\mathrm{a}$ & 0.0089 & 0.0064 & 0.0077 & 0.0007 & 0.0088 & 0.0067 \\
\hline $\mathrm{b}$ & 0.0082 & 0.0038 & 0.0067 & 0.0018 & 0.0082 & 0.0027 \\
\hline $\mathrm{c}$ & 0.013 & 0.0048 & 0.0075 & 0.0025 & 0.0131 & 0.0133 \\
\hline $\mathrm{d}$ & 0.0054 & 0.0019 & 0.0026 & 0.0012 & 0.0054 & 0.0143 \\
\hline $\mathrm{e}$ & 0.0114 & 0.0055 & 0.0111 & 0.0017 & 0.0113 & 0.0104 \\
\hline $\mathrm{f}$ & 0.012 & 0.0034 & 0.0083 & 0.0016 & 0.0118 & 0.0089 \\
\hline uji & 0.0081 & 0.0037 & 0.0091 & 0.0018 & 0.0081 & \\
\hline \multicolumn{7}{|c|}{ Rata-rata jarak data latih dengan data uji } \\
\hline
\end{tabular}

Hasil pengujian dapat dilihat bahwa penggunaan fitur gabungan lebih bagus menghasilkan nilai hasil pengujian pencarian gambar untuk kategori gambar gajah. Pengujian untuk gambar kategori gajah memperlihatkan bahwa nilai recall sebesar 1 dan precisión sebesar 0,24. Hasil pencarian gambar dengan menggunakan gambar berkategori gajah terlihat pada gambar 9 .

TABEL 5Hasil pengujian pencarian gambar kategori Gajah

\begin{tabular}{|c|c|c|c|c|c|c|c|c|}
\hline \multirow{2}{*}{ Gambar } & \multicolumn{5}{|c|}{ Rata-rata Pengujian Hasil Pencarian Gambar } \\
\cline { 2 - 9 } & \multicolumn{5}{|c|}{ Recall } & \multicolumn{5}{c|}{ Precision } \\
\cline { 2 - 9 } & Warna & Tekstus & Bentuk & Gabungan & Warna & Tekstur & Bentuk & Gabungan \\
\hline a & 1 & 0.69 & 1 & 0.66 & 0.24 & 0.22 & 0.18 & 0.26 \\
\hline b & 1 & 0.68 & 1 & 0.67 & 0.28 & 0.24 & 0.20 & 0.26 \\
\hline c & 1 & 0.66 & 1 & 0.63 & 0.25 & 0.19 & 0.13 & 0.22 \\
\hline d & 1 & 0.69 & 1 & 0.85 & 0.17 & 0.22 & 0.12 & 0.22 \\
\hline e & 1 & 0.68 & 1 & 0.64 & 0.15 & 0.20 & 0.17 & 0.21 \\
\hline f & 1 & 0.54 & 1 & 0.61 & 0.30 & 0.20 & 0.16 & 0.24 \\
\hline Rata-rata & 1 & 0.66 & 1 & 0.68 & 0.23 & 0.21 & 0.16 & 0.24 \\
\hline
\end{tabular}

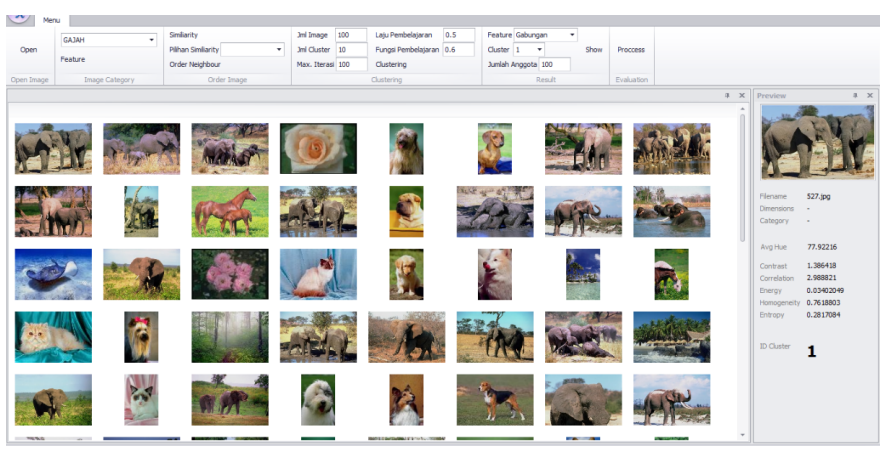

Gambar9: Hasil Pengujian Sistem Data Uji Kategori Gajah

Hasil pengukuran hasil pencarian gambar kategori bus terlihat pada tabel 6 .

TABEL 6Hasil Pengukuran Pencarian Gambar Kategori Bus

\begin{tabular}{|c|c|c|c|c|}
\hline \multirow[t]{2}{*}{ Gambar Uji } & \multirow[t]{2}{*}{ Fitur } & \multirow{2}{*}{$\begin{array}{c}\text { Jml } \\
\text { Gambar }\end{array}$} & \multicolumn{2}{|c|}{ Retrieval } \\
\hline & & & Recall & Precision \\
\hline-16 & Warna & 100 & 1 & 0.29 \\
\hline & Tekstur & 100 & 1 & 0.45 \\
\hline
\end{tabular}

I Gusti Rai Agung Sugiartha:Ekstraksi Fitur Warna, Tekstur....

\begin{tabular}{|c|l|c|c|c|}
\hline Gambar Uji & Fitur & \multirow{2}{*}{$\begin{array}{c}\text { Jml } \\
\text { Gambar }\end{array}$} & \multicolumn{2}{|c|}{ Retrieval } \\
\cline { 4 - 5 } & & Recall & Precision \\
\cline { 2 - 5 } & Bentuk & 100 & 1 & 0.6 \\
\cline { 2 - 5 } & Gabungan & 100 & 1 & 0.45 \\
\cline { 2 - 5 } & Warna & 200 & 1 & 0.25 \\
\cline { 2 - 5 } & Tekstur & 200 & 1 & 0.34 \\
\cline { 2 - 5 } & Bentuk & 200 & 1 & 0.44 \\
\cline { 2 - 5 } & Gabungan & 200 & 1 & 0.34 \\
\cline { 2 - 5 } & Warna & 300 & 1 & 0.21 \\
\cline { 2 - 5 } & Tekstur & 300 & 0.54 & 0.32 \\
\cline { 2 - 5 } & Bentuk & 300 & 1 & 0.32 \\
\cline { 2 - 5 } & Gabungan & 300 & 0.53 & 0.33 \\
\hline
\end{tabular}

Pengukuran kualitas masing-masing hasil ektraksi fitur menggunakan beberapa gambar latih, dimana gambar latih yang dipergunakan adalah gambar latih yang memiliki nilai kedekatan paling kecil dengan gambar uji. Gambar latih yang dipergunakan terlihat di gambar 10.

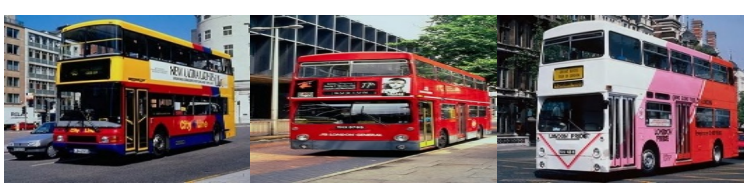

(a)

(b)

(c)

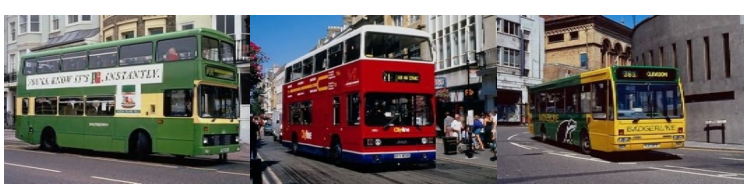

(d)

(e)

(f)

Gambar10: Gambar latih jarak kedekatan terkecil dengan gambar uji kategori bus

Perhitungan jarak nilai fitur gambar uji dengan fitur gambar latih diperlihatkan pada tabel 7 untuk fitur warna, tabel 8 untuk fitur tekstur, dan tabel 9 untuk fitur bentuk.

TABEL 7Hasil Pengukuran jarak fitur Warna kategori Bus

\begin{tabular}{|c|c|c|c|c|c|c|c|c|c|}
\hline \multirow{2}{*}{ Gambar } & \multicolumn{7}{|c|}{ Fitur Warna } & $\begin{array}{c}\text { Jarak } \\
\text { (Manhattan } \\
\text { Distance })\end{array}$ \\
\cline { 2 - 9 } & 1 & 2 & 3 & 4 & 5 & 6 & 7 & 8 & 0.3612 \\
\hline $\mathrm{a}$ & 0.2981 & 0.1047 & 0.1594 & 0.1551 & 0.0847 & 0.0873 & 0.1006 & 0.0101 & 0.4374 \\
\hline $\mathrm{b}$ & 0.18 & 0.1921 & 0.1482 & 0.1485 & 0.1231 & 0.1097 & 0.0761 & 0.0223 & 0.3069 \\
\hline $\mathrm{c}$ & 0.2584 & 0.1491 & 0.1512 & 0.087 & 0.1085 & 0.0834 & 0.1379 & 0.0244 & 0.6932 \\
\hline $\mathrm{d}$ & 0.1392 & 0.0772 & 0.2726 & 0.2343 & 0.0668 & 0.067 & 0.1011 & 0.0418 & 0.3566 \\
\hline $\mathrm{e}$ & 0.2895 & 0.242 & 0.1149 & 0.1301 & 0.0885 & 0.0604 & 0.0473 & 0.0273 & 0.5473 \\
\hline $\mathrm{f}$ & 0.1972 & 0.0991 & 0.1671 & 0.3136 & 0.0952 & 0.0684 & 0.0529 & 0.0066 & \\
\hline uji & 0.281 & 0.117 & 0.1297 & 0.0877 & 0.2318 & 0.058 & 0.0635 & 0.0313 & \multicolumn{7}{|c|}{ Rata-rata jarak data latih dengan data uji } & 0.4504 \\
\hline
\end{tabular}

TABEL 8 Hasil Pengukuran jarak fitur Tekstur kategori Bus

p-ISSN:1693 - 2951; e-ISSN: 2503-2372 


\begin{tabular}{|c|c|c|c|c|c|c|}
\hline \multirow{2}{*}{ Gambar } & \multicolumn{5}{|c|}{ Fitur Tekstur } & \multirow{2}{*}{$\begin{array}{c}\text { Jarak } \\
\text { (Manhattan Distance) }\end{array}$} \\
\hline & Contrast & Correlation & Energy & Homogenity & Entropy & \\
\hline $\mathrm{a}$ & 4.5305 & 0.0499 & 0.7032 & 9.9276 & 0.3014 & 1.656 \\
\hline $\mathrm{b}$ & 5.7888 & 0.0209 & 0.6397 & 7.4348 & 0.2418 & 2.2472 \\
\hline $\mathrm{c}$ & 5.4353 & 0.0304 & 0.6667 & 11.6831 & 0.2628 & 2.5425 \\
\hline d & 4.2114 & 0.0364 & 0.6847 & 5.7601 & 0.2766 & 5.1058 \\
\hline $\mathrm{e}$ & 4.524 & 0.0423 & 0.6967 & 8.7971 & 0.2879 & 1.7454 \\
\hline $\mathrm{f}$ & 3.8642 & 0.0332 & 0.6755 & 4.59 & 0.2717 & 6.6404 \\
\hline uji & 5.6397 & 0.0455 & 0.6875 & 9.4102 & 0.2921 & \\
\hline \multicolumn{6}{|c|}{ Rata-rata jarak data latih dengan data uji } & 3.3229 \\
\hline
\end{tabular}

TABEL 9 Hasil Pengukuran jarak fitur Bentuk kategori Bus

\begin{tabular}{|c|c|c|c|c|c|c|}
\hline \multirow{2}{*}{ Gambar } & \multicolumn{5}{|c|}{ Fitur Bentuk } & \multirow{2}{*}{$\begin{array}{c}\text { Jarak } \\
\text { (Manhattan Distance) }\end{array}$} \\
\cline { 2 - 6 } & $0^{0}$ & $45^{0}$ & $90^{0}$ & $135^{0}$ & $180^{0}$ & \\
\hline $\mathrm{a}$ & 0.026 & 0.0018 & 0.0267 & 0.0009 & 0.026 & 0.0176 \\
\hline $\mathrm{b}$ & 0.0282 & 0.0052 & 0.0247 & 0.0027 & 0.028 & 0.019 \\
\hline $\mathrm{c}$ & 0.0287 & 0.0053 & 0.0225 & 0.0027 & 0.0285 & 0.0203 \\
\hline $\mathrm{d}$ & 0.0228 & 0.0016 & 0.0292 & 0.0007 & 0.0225 & 0.0222 \\
\hline $\mathrm{e}$ & 0.0265 & 0.007 & 0.0204 & 0.0015 & 0.0262 & 0.0274 \\
\hline $\mathrm{f}$ & 0.0226 & 0.002 & 0.0231 & 0.0006 & 0.0226 & 0.0281 \\
\hline uji & 0.0317 & 0.0023 & 0.0321 & 0.0012 & 0.0317 & \\
\hline & & & & & & 0.0224 \\
\hline
\end{tabular}

Hasil pengujian dapat dilihat bahwa penggunaan fitur bentuk lebih bagus menghasilkan nilai hasil pengujian pencarian gambar untuk kategori gambar bus. Pengujian untuk gambar kategori bus memperlihatkan bahwa nilai recall sebesar 1 dan precisión sebesar 0,44. Hasil pencarian gambar dengan menggunakan gambar berkategori bus terlihat pada gambar 11 .

TABEL 10Hasil pengujian pencarian gambar kategori Bus

\begin{tabular}{|c|c|c|c|c|c|c|c|c|}
\hline \multirow{2}{*}{ Gambar } & \multicolumn{6}{|c|}{ Rata-rata Pengujian Hasil Pencarian Gambar } \\
\cline { 2 - 9 } & \multicolumn{5}{|c|}{ Recall } & \multicolumn{4}{c|}{ Precision } \\
\cline { 2 - 9 } & Warna & Tekstus & Bentuk & Gabungan & Warna & Tekstur & Bentuk & Gabungan \\
\hline a & 1 & 0.84 & 1 & 0.83 & 0.28 & 0.37 & 0.50 & 0.38 \\
\hline b & 1 & 0.73 & 1 & 1 & 0.24 & 0.23 & 0.40 & 0.27 \\
\hline c & 1 & 0.83 & 1 & 1 & 0.31 & 0.34 & 0.37 & 0.35 \\
\hline d & 1 & 0.92 & 1 & 0.84 & 0.07 & 0.24 & 0.53 & 0.26 \\
\hline e & 1 & 1 & 1 & 0.84 & 0.23 & 0.35 & 0.34 & 0.39 \\
\hline f & 1 & 0.88 & 1 & 0.70 & 0.22 & 0.16 & 0.50 & 0.14 \\
\hline Rata-rata & 1 & 0.87 & 1 & 0.87 & 0.22 & 0.28 & 0.44 & 0.30 \\
\hline
\end{tabular}

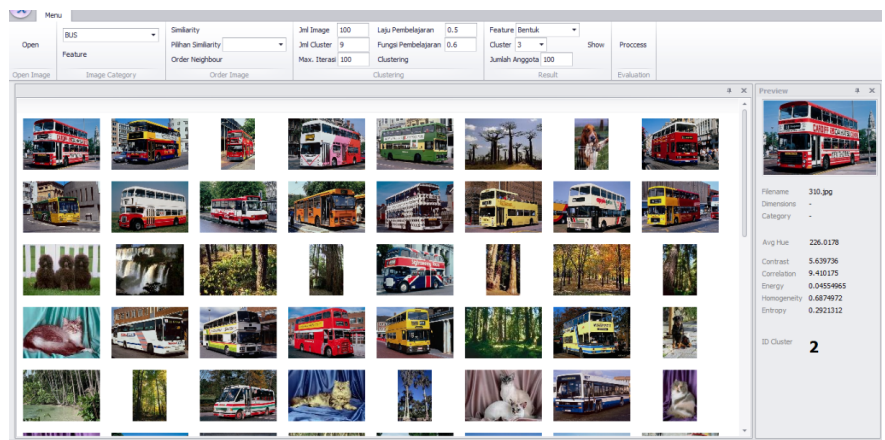

Gambar11: Hasil Pengujian Sistem Data Uji Kategori Gajah

\section{KESIMPULAN}

Sistem image retrievalyang dikembangkan mampu menghasilkan pencarian gambar sesuai dengan gambar uji. Proses preprocessing menggunakan pengubahan gambar berwarna ke gambar abu-abu(grayscale) yang berfungsi untuk menyederhanakan warna gambar latih dan gambar uji agar lebih mudah untuk pengambilan fitur. Pengambilan fitur gambar menggunakan 3 metode yaitu ekstraksi fitur warna dengan color histogram 8 bin, ekstraksi fitur tekstur dengan GLCM (Gray Level oCcurance Matrix), dan fitur bentuk dengan metode edge direction 5 arah dan metode Canny sebagai deteksi tepi. Pengujian hasil pencarian gambar menggunakan recall dan precision.Hasil pengukuran pencarian citra dengan metode recall dan precision diatas 0.8 dari rentang nilai 0 sampai dengan 1 , hal ini menunjukkan bahwa sistem sudah bisa memberikan hasil pencarian gambar yang bagus sesuai dengan citra uji yang digunakan. Nilai pengukuran pencarian gambar menunjukkan penggunaan fitur bentuk memiliki nilai pengukuran tertinggi, ini disebabkan karena data latih dan data uji dari kategori gajah dan bus memiliki bentuk objek yang khusus dan sangat berbeda dengan bentuk objek dari kategori gambar yang lainnya. Semakin banyak objek dan komposisi warna yang menjadi warna latar di suatu gambar menghasilkan fitur-fitur yang menyulitkan untuk dikelompokkan.

\section{REFERENSI}

[1] Chen, Yixin. 2004. Machine Learning and Statistical Modelling Approaches To Image Retrieval.Kluwer Acedemic Publisher:Boston

[2] Parker, J.R. 2011. Algorithms for Image Processing and Computer Vision. Indianapolis: Wiley Publishing, Inc

[3] Raghavan, Vijay. 1989. A Critical Investigation of Recaal and Precision as Measures of Retireval System Performance. ACM Transactions on Information Systems, Vol.7, Hal 205-229

[4] J. Z. Wang, J. Li, and G. Wiedehold. 2001. SIMPLIcity: SemanticsSensitive Integrated Matching for Picture Libraries. IEEE Transactions on Pattern Analysis and Machine Intelligence, vol. 23 : 947-963

[5] Ferguson, Jeremiah R. 2007. Using the Gray-Level Co-Occurrence Matrix to Segment and Classify Radar Imagery. Reno: University of Nevada

[6] Madhulata, Soni. 2012. An Overview On Clustering Methods. IOSR Journal of Engineering, Vol2(4), Hal: 719-725 